Annals of Plant and Soil Research 23(3): 304-309 (2021)

https://doi.org/10.47815/apsr.2021.10074

\title{
Effect of media and foliar concoction on growth, yield and quality of Dracaena (Dracaena reflexa 'Variegata') as cut foliage
}

\author{
GOWSHIKA DEVI, M AND P. KARUPPAIAH \\ Department of Horticulture (Floriculture and Landscape Architecture), Faculty of Agriculture, Annamalai \\ University, Tamil Nadu, India \\ Received: April, 2021: Revised accepted: June, 2021
}

\begin{abstract}
A study was conducted during the year 2018-2020 to find out a suitable potting media and foliar concoction to increase the growth, yield and quality of Dracaena reflexa 'Variegata' as cut foliage. The experiment was laid out in CRBD with 13 treatments and three replications. The various treatments significantly influenced the growth, yield and quality attributes of dracaena. Among the different treatments, $T_{12}$ (sand + vermicompost + red earth+ coir compost $+F Y M+$ burned rice husk (0.5:0.5:0.5:0.5:0.5:0.5 v/v) as potting media + foliar concoction spray of $1 \% 90: 90: 90 \mathrm{NPK}$ fertilizer $+0.4 \% \mathrm{FeSO}_{4}+0.2 \% \mathrm{MgSO}_{4}+0.4 \% \mathrm{ZnSO}+0.2 \%$ boron $+0.3 \%$ copper $+0.1 \%$ molybdenum $+0.2 \%$ manganese $+0.1 \%$ cobalt $+0.5 \%$ sea weed extract +250 ppm brassinosteroid at monthly interval) was found to be the best in growth and yield attributes such as plant height $(63.4 \mathrm{~cm})$, plant spread $\left(192.4 \mathrm{~cm}^{2}\right)$, leaves per plant $(45.9)$, leaf length $(57.8 \mathrm{~cm})$, leaf width $(6.1 \mathrm{~cm})$,leaf area $\left(300.1 \mathrm{~cm}^{2}\right)$, relative growth rate $\left(0.07 \mathrm{~cm} \mathrm{day}^{-1}\right)$, chlorophyll content $(17.2$ SPAD value), root length (53.8 $\mathrm{cm})$, single leaf weight (22.2 g), shoot fresh weight per plant (717.2 g), root fresh weight per plant (386.2 g), total plant fresh weight (1103.4 g), dry matter production $(441.3 \mathrm{~g})$ and leaf yield per plant 36.2 on 270 days after planting. Quality characters like longevity of the leaves in the plant (47.4 days) and visual scoring (9.8), freshness index (88.4), colour index (89), vase life without pulsing(9.9 days) and vase life with pulsing(18.8 days) of the cut foliage of the dracaena were also noted high in $T_{12}$. Control $\left(T_{13}\right)$ recorded the minimum in growth and yield attributes of dracaena such as plant height $(33.8 \mathrm{~cm})$, plant spread $\left(85.2 \mathrm{~cm}^{2}\right)$, leaves per plant (25.6), leaf length $(36.1 \mathrm{~cm})$, leaf width $(2.1 \mathrm{~cm})$, leaf area $\left(82.8 \mathrm{~cm}^{2}\right)$, relative growth rate $\left(0.03 \mathrm{~cm} \mathrm{day}^{-1}\right)$, chlorophyll content (10.6 SPAD value), root length $(28.4 \mathrm{~cm})$, single leaf weight $(13.9 \mathrm{~g})$, shoot fresh weight per plant $(258.7 \mathrm{~g})$, root fresh weight per plant $(139.3 \mathrm{~g})$, total plant fresh weight $(398.1 \mathrm{~g})$, dry matter production (159.3 g) and leaf yield per plant (15.6) on 270 DAP, while the quality characters like longevity of the leaves in the plant (35.9 days) and visual scoring (5.6), freshness index (68.4), colour index (69.8), vase life without pulsing (3.8 days) and vase life with pulsing (8.9 days) of the cut foliage of the dracaena were recorded the least.
\end{abstract}

Key words: Dracaena, foliar concoction, micronutrients, seaweed extract and brassinosteroid.

\section{INTRODUCTION}

Floriculture industry is one of the most dynamic and fast growing industry, which has achieved significant rate of growth during the past few years and has extended worldwide with the major paradigm shift of production centres from developed to developing countries. India is on the $18^{\text {th }}$ rank with contributing 0.6 percent share in global floriculture trade. India has exported 19726.57 MT of floriculture products to the world for the worth of Rs. 517.38 crores in 2018-19. In the present scenario of increasing demand for cut foliage, protected cultivation of ornamental plants in partial green houses and shade net houses in pots or other containers are the best alternative for using land and other resources more efficiently for cut foliage production (Anand et al., 2020). Dracaena reflexa is known as the 'Song of India' and 'Pleomele' used as a valuable ornamental and landscaping plant for tropical and subtropical gardens. It is an evergreen, perennial plant with growth habits of tree and shrub. Growing substrates respond differently for different plant groups by improving structure, texture, aeration and water holding capacity of the growing media for a potted ornamental plant. Fertilization is also one of the most important cultural practice that affect growth, aesthetic appeal and ornamental values of foliage plants. Micronutrients play a major role in foliage plants. Zinc plays a significant role in plant resistance against biotic and abiotic stress, photosynthesis, cell membraneintegrity, protein synthesis, pollen formation and enhances the level of antioxidant enzymes and chlorophyll within plant tissues (Azhar Hussain et al., 2015). Iron helps in growth 
of the plants on limiting factors. Magnesium is an essential mineral nutrient for plant which includes increased resistance of tissues in balance with other minerals and is an underutilized tool for disease control. Boron plays a major role in cell wall synthesis, cell division, translocation of sugars, carbohydrates and nitrogen fixation. Molybdenum aids in enzyme catalyzing the various oxidationreduction reaction in plants (Khosa et al., 2011). Normally ornamental plants require a wide range of nutrients for their better growth, development, aesthetic appeal and other ornamental values. The plant growth regulators conduct a decisive role in various facts of growth and development, leaf senescence and stress responses of the ornamental plants. Application of organic sources through growing substrate and foliar application of inorganic macro and micro nutrients, plant growth regulating substances have a vital role in growth and development of the plant grown in potting media. The foliar application of macro and micronutrients with the growth regulators and bio stimulates or bio inhibitors are active even at very low concentration in plant cells and have the ability to alter the growth and development (Yassar Sajjad et al., 2017). The available information regarding the impact of growing media and foliar concoction on the foliage ornamental plants are scanty. Keeping in view of the above facts, the present study was undertaken.

\section{MATERIALS AND METHOD}

The present study was carried out at Annamalai University, Annamalai Nagar during the 2018-2019 and 2019-2020. The experiment was laid out in CRBD with 13 treatments and three replications. The treatments used in the study were $T_{1}$ (sand +red earth+ FYM $(1: 1: 1 \mathrm{v} / \mathrm{v})$, $\mathrm{T}_{2}$ (vermicompost + coir compost + FYM + burned rice husk (0.75:0.75:0.75:0.75 v/v), $T_{3}$ (sand + vermicompost + red earth + coir compost $+\mathrm{FYM}+$ burned rice husk (0.5:0.5:0.5:0.5:0.5:0.5 v/v), $\mathrm{T}_{4}\left(\mathrm{~T}_{1}\right.$ (sand +red earth+ FYM $(1: 1: 1 \mathrm{v} / \mathrm{v})$ as potting media)+ foliar concoction spray of $1 \%$ 90:90:90 NPK fertilizer + $0.4 \% \mathrm{FeSO}_{4}+0.2 \% \mathrm{MgSO}_{4}+0.4 \% \mathrm{ZnSO}_{4}+0.2 \%$ boron $+0.3 \%$ copper $+0.1 \%$ molybdenum + $0.2 \%$ manganese $+0.1 \%$ cobalt $+0.5 \%$ sea weed extract $+250 \mathrm{ppm}$ gibberellic acid (foliar concoction $I), T_{5}$ ( $T_{1}$ (sand +red earth+ FYM
$(1: 1: 1 \mathrm{v} / \mathrm{v})$ as potting media)+ foliar concoction spray of 1\%90:90:90 NPK fertilizer $+0.4 \%$ $\mathrm{FeSO}_{4}+0.2 \% \mathrm{MgSO}_{4}+0.4 \% \mathrm{ZnSO}_{4}+0.2 \%$ boron $+0.3 \%$ copper $+0.1 \%$ molybdenum $+0.2 \%$ manganese $+0.1 \%$ cobalt $+0.5 \%$ sea weed extract $+250 \mathrm{ppm}$ benzyl adenine (foliar concoction II), $T_{6} \quad\left(T_{1}\right.$ (sand +red earth+ FYM $(1: 1: 1 \mathrm{v} / \mathrm{v})$ as potting media $)+$ foliar concoction spray of 1\%90:90:90 NPK fertilizer + 0.4\% $\mathrm{FeSO}_{4}+0.2 \% \mathrm{MgSO}_{4}+0.4 \% \mathrm{ZnSO}_{4}+0.2 \%$ boron $+0.3 \%$ copper $+0.1 \%$ molybdenum $+0.2 \%$ manganese $+0.1 \%$ cobalt $+0.5 \%$ sea weed extract $+250 \mathrm{ppm}$ brassinosteroid (foliar concoction III), $\mathrm{T}_{7}\left(\mathrm{~T}_{2}\right.$ (vermicompost + coir compost + FYM + burned rice husk $(0.75: 0.75: 0.75: 0.75 \mathrm{v} / \mathrm{v})$ as potting media)+ foliar concoction spray of 1\%90:90:90 NPK fertilizer+0.4\% $\quad \mathrm{FeSO}_{4}+0.2 \% \quad \mathrm{MgSO}_{4}+0.4 \%$ $\mathrm{ZnSO}_{4}+0.2 \%$ boron $+0.3 \%$ copper $+0.1 \%$ molybdenum $+0.2 \%$ manganese $+0.1 \%$ cobalt $+0.5 \%$ sea weed extract $+250 \mathrm{ppm}$ gibberellic acid), $T_{8} \quad\left(T_{2}\right.$ (vermicompost + coir compost + FYM + burned rice husk (0.75:0.75:0.75:0.75 $\mathrm{v} / \mathrm{v}$ ) as potting media)+ foliar concoction spray of 1\%90:90:90 NPK fertilizer + 0.4\% $\mathrm{FeSO}_{4}+0.2 \%$ $\mathrm{MgSO}_{4}+0.4 \% \mathrm{ZnSO}_{4}+0.2 \%$ boron $+0.3 \%$ copper $+0.1 \%$ molybdenum $+0.2 \%$ manganese $+0.1 \%$ cobalt $+0.5 \%$ sea weed extract +250 ppm benzyl adenine), $T_{9} \quad\left(T_{2}\right.$ (vermicompost + coir compost + FYM + burned rice husk $(0.75: 0.75: 0.75: 0.75 \mathrm{v} / \mathrm{v})$ as potting media)+ foliar concoction spray of 1\%90:90:90 NPK fertilizer $+0.4 \% \quad \mathrm{FeSO}_{4}+0.2 \% \quad \mathrm{MgSO}_{4}+0.4 \%$ $\mathrm{ZnSO}_{4}+0.2 \%$ boron $+0.3 \%$ copper $+0.1 \%$ molybdenum $+0.2 \%$ manganese $+0.1 \%$ cobalt $+0.5 \%$ sea weed extract $+250 \mathrm{ppm}$ brassinosteroid), $T_{10}\left(T_{3}\right.$ (sand + vermicompost + red earth + coir compost + FYM + burned rice husk (0.5:0.5:0.5:0.5:0.5:0.5 v/v) as potting media)+ foliar concoction spray of $1 \% 90: 90: 90$ $\mathrm{NPK}$ fertilizer $+0.4 \% \mathrm{FeSO}_{4}+0.2 \% \mathrm{MgSO}_{4}+0.4$ $\% \mathrm{ZnSO}_{4}+0.2 \%$ boron $+0.3 \%$ copper $+0.1 \%$ molybdenum $+0.2 \%$ manganese $+0.1 \%$ cobalt $+0.5 \%$ sea weed extract $+250 \mathrm{ppm}$ gibberellic acid ) $T_{11}\left(T_{3}\right.$ (sand + vermicompost + red earth + coir compost + FYM + burned rice husk (0.5:0.5:0.5:0.5:0.5:0.5 v/v) as potting media) + foliar concoction spray of 1\%90:90:90 NPK fertilizer $+0.4 \% \mathrm{FeSO}_{4}+0.2 \% \mathrm{MgSO}_{4}+0.4 \%$ $\mathrm{ZnSO}_{4}+0.2 \%$ boron $+0.3 \%$ copper $+0.1 \%$ molybdenum $+0.2 \%$ manganese $+0.1 \%$ cobalt $+0.5 \%$ sea weed extract $+250 \mathrm{ppm}$ benzyl adenine) and $T_{12} \quad\left(T_{3}\right.$ (sand + vermicompost + 
red earth + coir compost + FYM + burned rice husk (0.5:0.5:0.5:0.5:0.5:0.5 v/v) as potting media) + foliar concoction spray of $1 \% 90: 90: 90$ $\mathrm{NPK}$ fertilizer $+0.4 \% \mathrm{FeSO}_{4}+0.2 \% \mathrm{MgSO}_{4}+0.4$ $\% \mathrm{ZnSO}_{4}+0.2 \%$ boron $+0.3 \%$ copper $+0.1 \%$ molybdenum $+0.2 \%$ manganese $+0.1 \%$ cobalt $+0.5 \%$ sea weed extract $+250 \mathrm{ppm}$ brassinosteroid) which were made as media and foliar concoction at monthly intervals from the date of planting, individually and in combination with each other. Healthy plants of Dracaena reflexa 'Variegata' of uniform size of about $15 \mathrm{~cm}$ height were potted to the pots of 1 foot size. The potting media were prepared by mixing various media such as sand, red earth, FYM, vermicompost, coir compost and burned rice husk in different ratio according to the treatment schedule. The control treatment plants were maintained with the garden soil and water spray. Irrigation was done for the plants once in a week depending on the moisture content in the media and climatic conditions. Maintenance including plant protection measures were carried out as per the need of the plant.

Foliar concoctions were prepared as per the treatment schedule by mixing $10 \mathrm{~g}$ of 90:90:90 NPK fertilizer, $4 \mathrm{~g}$ each of $\mathrm{FeSO}_{4}$ and $\mathrm{ZnSO}_{4}, \quad 2 \mathrm{~g}$ each of $\mathrm{MgSO}_{4}$, boron and manganese, $3 \mathrm{~g}$ of copper, $1 \mathrm{~g}$ each of molybdenum and cobalt per litre of water. The seaweed extract is in liquid formulation and $5 \mathrm{ml}$ per litre was used. $\mathrm{GA}_{3}$, benzyl adenine and brassinosteroid of $250 \mathrm{ppm}$ solutions were prepared by dissolving $0.25 \mathrm{~g}$ each in small amount of ethanol and then mixed in one litre of concoction spray. The required volume of foliar concoction was prepared and spray was given at monthly intervals from the date of planting. The biometric observations like growth, physiological and yield parameters such as plant height $(\mathrm{cm})$, plant spread $\left(\mathrm{cm}^{2}\right)$, leaves per plant, leaf length $(\mathrm{cm})$, leaf width, leaf area $\left(\mathrm{cm}^{2}\right)$, relative growth rate $\left(\mathrm{cm}\right.$ day $\left.^{-1}\right)$, chlorophyll content (SPAD value), root length, single leaf weight, shoot fresh weight per plant $(\mathrm{g})$, root fresh weight per plant $(\mathrm{g})$, total plant fresh weight, dry matter production, leaf yield per plant and longevity of the leaves in the plant (days) were recorded 270 Days After Planting. The quality attributes viz, visual scoring, freshness index and colour index of the cut foliage were recorded as per the Hedonic sensory evaluation. Vase life without pulsing (days) and vase life with pulsing (days) of the cut foliage in every treatment replications were noted under room temperature. Fifth leaf from the top was used as index leaf to measure the biometric observations. The data on various parameters were analysed statistically as per the procedure suggested by Panse and Sukhatme (1997).

\section{RESULTS AND DISCUSSION}

The various treatments significantly influenced the plant growth, yield and quality characters of Dracaena. The data on growth parameters (Table 1) revealed that the maximum plant height and plant spread were significantly increased with the $T_{12} \quad\left(T_{3^{-}}\right.$sand + vermicompost+ red earth+ coir compost+ $\mathrm{FYM}+$ burned rice husk (0.5:0.5:0.5:0.5:0.5:0.5 v/v) as potting media + foliar concoction spray of $1 \%$ 90:90:90 NPK fertilizer $+0.4 \% \mathrm{FeSO}_{4}+0.2 \%$ $\mathrm{MgSO}_{4}+0.4 \% \mathrm{ZnSO}_{4}+0.2 \%$ boron $+0.3 \%$ copper $+0.1 \%$ molybdenum $+0.2 \%$ manganese $+0.1 \%$ cobalt $+0.5 \%$ sea weed extract +250 ppm brassinosteroid (foliar concoction III)with the value of $63.4 \mathrm{~cm}$ and $192.4 \mathrm{~cm}^{2}$, followed by $\mathrm{T}_{10}\left[\mathrm{~T}_{3}\right.$ (sand + vermicompost + red earth + coir compost + FYM + burned rice husk $(0.5: 0.5: 0.5: 0.5: 0.5: 0.5 \mathrm{v} / \mathrm{v})$ as potting media) + foliar concoction spray of $1 \%$ 90:90:90 NPK fertilizer + 0. $4 \% \mathrm{FeSO}_{4}+0.2 \% \mathrm{MgSO}_{4}+0.4 \%$ $\mathrm{ZnSO}_{4}+2 \%$ boron $+0.3 \%$ copper $+0.1 \%$ molybdenum $+0.2 \%$ manganese $+0.1 \%$ cobalt + $0.5 \%$ sea weed extract $+250 \mathrm{ppm}$ gibberellic acid (foliar concoction I) with the values of 61.4 $\mathrm{cm}$ and $183.4 \mathrm{~cm}^{2}$. The minimum plant height and plant spread were $33.8 \mathrm{~cm}$ and 85.1 $\mathrm{cm}^{2}$ whichrecorded in control. The increase in plant height and spread might be due to the supplementation of nutrients through different combination of media and foliar concoction containing the macro and micronutrients, biostimulators and growth regulators which might increase cell wall tension, cell division, cell elongation and more water absorption to cell and at last increase in plant height and plant spread as reported by Sankari, (2019) in Asparagus sprengeri. 
Table 1: Effect of media and foliar concoction on growth parameters ofDracaena reflexa'Variegata' at 270 days after planting

\begin{tabular}{|c|c|c|c|c|c|c|c|c|c|c|c|c|c|c|}
\hline Treatments & $\begin{array}{l}\text { Plant } \\
\text { height } \\
(\mathrm{cm})\end{array}$ & $\begin{array}{c}\text { Plant } \\
\text { spread } \\
\left(\mathrm{cm}^{2}\right)\end{array}$ & $\begin{array}{l}\text { Leave } \\
\text { s per } \\
\text { plant }\end{array}$ & $\begin{array}{l}\text { Length } \\
\text { of the } \\
\text { leaf } \\
(\mathrm{cm})\end{array}$ & $\begin{array}{l}\text { Width } \\
\text { of the } \\
\text { leaf } \\
(\mathrm{cm})\end{array}$ & \begin{tabular}{|l} 
Leaf \\
area \\
$\left(\mathrm{cm}^{2}\right)$
\end{tabular} & $\begin{array}{l}\text { Relative } \\
\text { growth } \\
\text { rate } \\
\text { (cm/day) }\end{array}$ & $\begin{array}{l}\text { Chlorophy } \\
\text { II content } \\
\text { (SPAD } \\
\text { Value) }\end{array}$ & $\begin{array}{l}\text { Root } \\
\text { length } \\
(\mathrm{cm})\end{array}$ & $\begin{array}{c}\text { Single } \\
\text { leaf } \\
\text { weight } \\
\text { (g) }\end{array}$ & \begin{tabular}{|c}
$\begin{array}{c}\text { Shoot } \\
\text { fresh } \\
\text { weight } \\
\text { (g) }\end{array}$ \\
\end{tabular} & \begin{tabular}{|c|} 
Root \\
fresh \\
weight \\
$(\mathrm{g})$
\end{tabular} & \begin{tabular}{|c|} 
Total \\
plant \\
fresh \\
weight (g)
\end{tabular} & $\begin{array}{c}\text { Dry } \\
\text { matter } \\
\text { prod. (g) }\end{array}$ \\
\hline$\overline{T_{1}}$ & 1 & 02.4 & 32.4 & 41.1 & 3.4 & 122.1 & 0.05 & 12.2 & & 15.8 & 364.6 & 196.3 & 560.9 & 843 \\
\hline $\mathrm{T}_{2}$ & & & & 39.4 & 3.2 & & & & & 15.2 & 329.3 & 77.3 & & \\
\hline $\mathrm{T}_{3}$ & & & & 4 & 3.7 & & & & & 16.5 & 9 & 3 & & \\
\hline $\mathrm{T}_{4}$ & & & & & 5.0 & & & & & & & & & \\
\hline$T$ & & & & 49 & 4.8 & & & & & 19.1 & & & & \\
\hline $\mathrm{T}_{6}$ & & & & 52.8 & 5.3 & & & & & 20.0 & & $329 . .2$ & & \\
\hline $\mathrm{T}_{7}$ & & & & 46 & 4.2 & & & & & 17.8 & & 253.3 & & \\
\hline $\mathrm{T}_{\varepsilon}$ & & & 3 & 44 & 4.0 & 1 & 0. & & & 17.1 & 435.1 & 234.3 & .4 & .8 \\
\hline $\mathrm{T}_{\mathrm{g}}$ & & & 3 & 47 & 4.5 & & 0 & & & 18.4 & 7 & 272.3 & & \\
\hline $\mathrm{T}_{10}$ & & & & & 5.8 & & & & & 21.6 & & 7.2 & & \\
\hline & & & & 5 & 5.5 & & & & & 20.9 & & 3.2 & & \\
\hline & & 4 & 45.2 & 57 & 6.1 & & 0. & & & 22.2 & 717.2 & 386.2 & 1103.4 & 41.4 \\
\hline & 33.8 & 85.2 & 25.6 & 36.1 & 2.1 & & 0. & & & 13.9 & 258.7 & 139.3 & 398.1 & 159.3 \\
\hline & & & & & 0.26 & & & & & 0.23 & & 4.98 & 7.52 & 8.70 \\
\hline $\begin{array}{c}C D \\
(P=0.05)\end{array}$ & $1 . \angle 0$ & 0 & 0.94 & 34 & 52 & 7.50 & & 0.38 & 8 & 16 & 3 & 77 & 04 & 17.40 \\
\hline
\end{tabular}

The number of leaves per plant, leaf length, leaf width, leaf area, relative growth rate and chlorophyll content were found to be the best in the $T_{12}$ with the values of $45.2,57.8 \mathrm{~cm}$, $6.1 \mathrm{~cm}, 300.1 \mathrm{~cm}^{2}, 0.07 \mathrm{~cm} /$ day and 17.2 SPAD value, followed by $T_{10}$ with the values of 43.9 , $56.2 \mathrm{~cm}, 5.8 \mathrm{~cm}, 279.0 \mathrm{~cm}^{2}, 0.07 \mathrm{~cm} /$ day and16.6 SPAD value respectively which were significantly superior with the control.(Table 1). Vetrivel et al., (2017) recorded the maximum number of leaves per plant due to the application of seaweed extract in chrysanthemum. Sagar et al., (2016) explained the positive and effective role of brassinosteroid in the improvement of plant growth. Foliar concoction stimulated the photosynthetic rate which increase the activity of some enzyme or change in distribution of photosynthetic materials and or participative effect of these cases, due to increase in effective level of number of leaves per plant, leaf length and width, leaf area, relative growth rate and chlorophyll content as reported by Ali Salehi Sardoei and Hassanpour (2014) in Schefflera.

The root length $(53.8 \mathrm{~cm})$, single leaf weight (22.2g), shoot fresh weight (717.2 $\mathrm{g} /$ plant), root fresh weight (386.2 $\mathrm{g} /$ plant), total plant fresh weight (1103.4 g/plant), dry matter production (441.3 g/plant)and leaf yield per plant (36.2) were recorded highest in $T_{12}\left(T_{3}\right.$ (sand + vermicompost + red earth + coir compost + FYM
+ burned rice husk (0.5:0.5:0.5:0.5:0.5:0.5 v/v) as potting media) + foliar concoction spray of $1 \%$ 90:90:90 NPK fertilizer + 0.4\% $\mathrm{FeSO}_{4}+0.2 \%$ $\mathrm{MgSO}_{4}+0.4 \% \mathrm{ZnSO}_{4}+2 \%$ borax $+0.3 \%$ copper $+0.1 \%$ molybdenum $+0.2 \%$ manganese $+0.1 \%$ cobalt $+0.5 \%$ sea weed extract $+250 \mathrm{ppm}$ brassinosteroid (foliar concoction III) compared to control. This might be due to the presence of appropriate physicochemical properties of the growing media along with foliar supplements in the best treatment. Micronutrients play vital roles in the growth and development of plants, due to their stimulatory and catalytic effects on metabolic processes and ultimately increased theoverall growth of plants as reported by Lahijie, (2012) in gladiolus and Khosa et al., (2011) in gerbera. The results are in line with the findings of Abinaya and Karuppaiah, (2018) in Philodendron erubescens.

The maximum longevity of the leaves in the plant (47.7 days) was recorded in $T_{12}$, followed by $T_{10}$ with the value of 46.2 days, while the minimum longevity of the leaves in the plant (35.9 days) was noticed in the control $\left(T_{13}\right)$. The quality characters viz., visual scoring (9.8), freshness index (88.4) and colour index (89.7) of the foliage were noticed to be the best in the treatment $\left(T_{12}\right)$, when compared with the control (Table 2). 
Table 2: Effect of media and foliar concoction on yield and quality parameters of Dracaena reflexa 'Variegata' at 270 days after planting

\begin{tabular}{|c|c|c|c|c|c|c|c|}
\hline Treatments & $\begin{array}{r}\text { Leaf } \\
\text { yield }\end{array}$ & $\begin{array}{c}\text { Longevity of leaves } \\
\text { in the plant (days) }\end{array}$ & $\begin{array}{c}\text { Visual } \\
\text { scoring }\end{array}$ & $\begin{array}{c}\text { Freshness } \\
\text { index }\end{array}$ & $\begin{array}{c}\text { Colour } \\
\text { index }\end{array}$ & $\begin{array}{c}\text { Vaselife without } \\
\text { pulsing (days) }\end{array}$ & $\begin{array}{c}\text { Vase life with } \\
\text { pulsing (days) }\end{array}$ \\
\hline $\mathrm{T}_{1}$ & 23.5 & 42.3 & 7.5 & 77.2 & 75.1 & 5.6 & 13.4 \\
$\mathrm{~T}_{2}$ & 22.2 & 41.8 & 7.1 & 76.0 & 73.5 & 5.2 & 12.9 \\
$\mathrm{~T}_{3}$ & 24.8 & 42.7 & 7.9 & 79.9 & 76.5 & 6.0 & 13.9 \\
$\mathrm{~T}_{4}$ & 31.3 & 44.9 & 8.8 & 84.1 & 83.6 & 7.7 & 16.1 \\
$\mathrm{~T}_{5}$ & 30.2 & 44.5 & 8.5 & 83.1 & 82.5 & 7.2 & 15.6 \\
$\mathrm{~T}_{6}$ & 32.7 & 45.4 & 9.0 & 85.2 & 85.1 & 8.1 & 16.5 \\
$\mathrm{~T}_{7}$ & 27.7 & 43.6 & 8.2 & 81.1 & 79.4 & 6.8 & 14.8 \\
$\mathrm{~T}_{8}$ & 26.3 & 43.2 & 8.1 & 80.2 & 77.9 & 6.3 & 14.3 \\
$\mathrm{~T}_{9}$ & 29.0 & 44.1 & 8.5 & 82.1 & 80.9 & 7.1 & 15.2 \\
$\mathrm{~T}_{10}$ & 34.9 & 46.2 & 9.3 & 87.4 & 88.2 & 9.1 & 17.4 \\
$\mathrm{~T}_{11}$ & 33.9 & 45.9 & 9.1 & 86.3 & 86.7 & 8.8 & 16.9 \\
$\mathrm{~T}_{12}$ & 36.2 & 47.7 & 9.8 & 88.5 & 89.8 & 9.9 & 18.9 \\
$\mathrm{~T}_{13}$ & 15.6 & 35.9 & 5.6 & 68.4 & 69.8 & 3.8 & 8.9 \\
$\mathrm{SD}$ & 0.39 & 0.44 & 0.12 & 0.48 & 0.53 & 0.30 & 0.45 \\
$\mathrm{CD}(\mathrm{P}=0.05)$ & 0.79 & 0.88 & 0.24 & 0.96 & 1.06 & 0.61 & 0.90 \\
\hline
\end{tabular}

The post harvest life of cut foliage as vase life of cut foliage without pulsing (9.9 days) and vase life of cut foliage with pulsing (18.8 days) were observed with the more number of days in $T_{12}$, followed by $T_{10}$ (9.1 and 17.4 day respectively) and the less number of days of vase life with and without pulsing(3.8 and 8.9 days respectively) were noticed with the control. The best treatment combination contains ideal growing media along with foliar supplementation of macro nutrients, other essential micro elements and growth boosters which are known to play a significant role in activating some enzymes and the accumulation of carbohydrate in plant cells and in turn increases leaf carbohydrate content and water potential. Water balance is a major factor influencing the quality andlongevity of cut flowers and foliage ( $\mathrm{Pal}$ et al., 2015). Vase life improvement might be due to weight retention, absorption capacity and water conductivity of leaf tissues as reported by Kjonboon and Kanlayanarat, (2004) in cut patumma and Abinaya and Karuppaiah, (2018) in Philodendron erubescens Cv.Gold.

From the present study, it may be concluded that application of sand + vermicompost + red earth + coir compost + FYM + burned rice husk (0.5:0.5:0.5:0.5:0.5:0.5 v/v) as potting media and a foliar concoction spray of 1\% 90:90:90 NPK fertilizer + 0. 4\% $\mathrm{FeSO}_{4}+$ $0.2 \% \mathrm{MgSO}_{4}+0.4 \% \mathrm{ZnSO}_{4}+2 \%$ boron $+0.3 \%$ copper $+0.1 \%$ molybdenum $+0.2 \%$ manganese $+0.1 \%$ cobalt $+0.5 \%$ sea weed extract +250 ppm brassinosteroid at monthly intervals proved significantly beneficial in respect of growth, physiological, yield and quality parameters of Dracaena reflexa 'Variegata' and its cut foliage production.

\section{REFERENCES}

Abinaya, S and Karuppaiah. P. (2018) Effect of organic foliar nutrition on growth, yield and quality of Philodendron erubenscens Cv. Gold. Ad. Plant Sci., 31 (2):85-90.

Ali Salehi Sardoei and Hassanpour Asil. M. (2014). Response on application of gibberellic acid and benzyladenine to Schefflera (Schefflera arboricola L.)

plants. Trends In Life Sciences. 3(2): 290-297.

Anand. M.,Kamalkumaran.P.R.,Velmurugan.M and Nandhakumar.S.(2020) Protected cultivation of cut foliage's in subtropical regions. Research Today. 2(5) Spl.: 161162. 
Azhar Hussain, Muhammad Arshad, Zahir Ahmad Zahir and Muhammad Asghar. (2015) Prospects of zinc solubilizing bacteria for enhancing growth of maize. Pak. Journal Agri. Sci., 52 (4): 915-922.

Khosa. S.S., Younis .A., Rayit. A., Yasmeen. S and Riaz. A. (2011) Effect of foliar application of macro and micro nutrients on growth and flowering of Gerbera jamesonni L. Amer. Euras. J. Agric. Environ. Sci., 11: 736-757.

Kjonboon. T and Kanlayanarat.S, (2004) Effect of gibberellic acid on the vase life of cut patumma (Curcuma alismatifolia Gagnep.) 'Chaing Mai' flowers. IX International Symposium On Flower Bulbs., 673: 525-529.

Lahijie. M.F. (2012). Application of micronutrients $\mathrm{FeSO}_{4}$ and $\mathrm{ZnSO}_{4}$ on the growth and development of Gladiolus Variety 'Oscar'. Int. J. Agric. Crop. Sci., 4:718-720.

Pal. V., Tyagi, A and Kumar .A.(2015). Influence of various preservative chemical on postharvest life of cut roses (Rosa hybrida L.) cv. 'Happiness'. South Asian J. Food Technology and Environment. 1: 274-278.
Panse. V.G and Sukhamte. P.V. (1978) Statistical methods for agricultural works II. Edn. ICAR New Delhi. India.

Sagar. A., Inderdeep Kaur, Piyush Mathur, Anirudh Mukherjee, Sagar Dhama, Vibhav Singh and Jasmeen Kaur. (2019) A New Concept in Organic Farming: Efficacy of Brassinosteroids as Foliar Spray to Ameliorate Growth of Marigold Plants. Environ. We Int. Sci. Tech., 14: 25-36.

Sankari. A. (2019) Effect of alternate media on growth of Asparagus sprengeri. Int. J. Chemical Studies. 7(3): 315-319.

Vetrivel. T., Jawaharlal, M, Arulmozhiyan. R. and Kannan. M. (2017) Effect of biostimulants on growth and yield of chrysanthemum (Dendranthema grandiflora Tzvelev) var. Amalfi under protected cultivation. Ecology, Environment and Conservation. 23(4): 2297- 2301.

Yassar Sajjad, Muhammad Jafar Jaskami, Asif. M. and Qasim.M. (2017) Application of growth regulators in ornamental plants: A review. Pak. Journal Agri. Sci., 54(2): 327-333. 